\title{
Increasing the Mental Toughness Through Match Simulations in a Basketball Game
}

\author{
Desmi Sartika*, Berliana Berliana, Komarudin Komarudin, Mesianna Simbolon, Alimin Hamzah, Puji Astuti \\ School of Postgraduate Studies \\ Faculty of Sport and Health Education, Universitas Pendidikan Indonesia \\ Bandung, Indonesia \\ *desmisartika@upi.edu
}

\begin{abstract}
In the current era, team sports are very popular and become the centre of attention. One of the most popular sports, both internationally and domestically, is basketball. Basketball not only supports physical training, but also must support tactical training. In general, mental toughness is a general term used by most athletes, coaches, and the media to understand mental characteristics that excel in training and competition. One method to improve mental toughness in basketball athletes is match simulation. Coaches and athletes deliberately carry out simulations in different forms of challenges according to the shape, content, time, place of origin, and difficulty level in basketball practice. In this regard, what happens in Indonesia is that every athlete has a different mental toughness in the match, both the winning compilation team and the losing compilation team. Here, the match simulation becomes one of the methods that can improve the mental toughness of an athlete.
\end{abstract}

Keywords: basketball game, match simulation, mental toughness

\section{INTRODUCTION}

In the current era, team sports are very popular and popular, and are the centre of attention [1]. One of the most popular sports both abroad and domestically is basketball. Basketball is a dynamic sport that involves the use of various types of basketball skills and player movements. Apart from training sessions, basketball not only involves the physical abilities of the athlete, but must combine some form of psychological pressure or simulation training.

One reason why the views of sports psychologists build mental toughness are important (and why they might be different) is that they need to potentially consult with coaches and sometimes parents, as well as athletes themselves, help athletes build mental toughness [2]. Therefore athletes, coaches, sports administrators, and the media widely recognize the importance of mental toughness as a key ingredient of performance excellence [3].

Athletes must be challenged to be completed and completed in a comfort zone, with training that can be seen as competitive and goal directed. Training sessions are not only in the area of athlete's physical abilities, but there must be some form of psychological training or training. This can complement the environment that is solved or which creates pressure and solves problems. The challenge is for coaches to be creative and for coaches who support to solve problems independently [4].

Basketball is a dynamic sport that involves the use of various types of basketball skills (e.g. dribbling, passing) and player movements [5]. During the game players perform various multi-directional movements such as running, dribbling, shuffling and jumping [6]. Many factors affect to improve the individual ability of a basketball team, in addition to basic technical training well, it can also overcome mental toughness. In human personality there are extrovert and introvert personality.

It is conceivable that emotionally stable athletes progress further in their sport because this is a desirable characteristic valued by coaches. Team sports generally involve a lot of communication and collaboration and are therefore best suited for extraverted individuals. On the other hand, participating in team sports is forced to communicate and cooperate with others so that it can help develop desirable personality characteristics such as extraversion. Introverts are introspective, analyse details, think carefully before speaking, and are comfortable working alone, so the orientation for an introvert is that they assess the situation or reflect on what has been learned before forming conclusions [7]. There are also athletes who have introverted characteristics, namely not social, passive, doubtful, quiet, many thoughts, sad, obedient, pessimistic, timid, closed, peaceful, calm, and controlled. Introverts tend to concentrate on activities in their own minds as opposed to their environment [8].

Some studies report fewer female students in sporting achievement. This is in accordance with research conducted by Wiley, who found that the participation of girls in the world of sports requires low [9]. Therefore, researchers are interested in examining ball sports in female extracurricular girls. Can be seen in a sample of North American adolescents, NeumarkSztainer, Goeden, Story, \& Wall, found a greater level of physical activity with greater body satisfaction among boys [10].

From preliminary observations of research in junior high schools in Purwakarta the basketball ball team from junior high schools was found that this was a finding of a mismatch as a team because they were not related to each other. However, 
these four teams have a passion for champions in the matches they participate in. This disharmony is because there are differences in the personality of the athlete. Personalities in this case such as extrovert, introvert, and ambivert. Therefore, there needs to be treatments that can unite / harmonize relationships within the basketball team such as increasing mental toughness which correlates with synergy between those related to athletes. In this regard, what happens in Indonesia every athlete has a different mental toughness in the match, both the compilation team wins and the losing compilation team. Here the match simulation becomes one of the methods that can improve the mental toughness of an athlete. Where the trainer still pays attention to the athlete's physical and technical readiness without regard to his mentality and personality. Extroverted, introverted, and ambitious personalities become the novelty idea of this research, by questioning studies that discuss increasing mental toughness through competition research has not yet produced the results. Can, it can be predicted, that this simulation technique has a higher level of significance to the increase in mental toughness towards athletes of extroverted and introverted personalities.

\section{THEORETICAL FRAMEWORK}

\section{A. Mental Toughness}

In general, mental toughness is a general term used by most athletes, coaches, and the media to describe the superior mental characteristics of athletes who excel in training and competition situations, while others fail. Especially at the elite level, it is a "mental game" that distinguishes players [11,12]. For example, mental skills have been shown to distinguish between "who gets there" athletes and those who "live there" [13], those who perform on the big stage and those who don't [11], and people who succeed in developing time for change / transition and the same method [14].

Mental toughness enhances research and psychological research, after capturing the imagination of the general sports community and the academic community. In fact, since Fourie and Potgieter [15] pioneered qualitative studies of mental resilience in South Africa, we have proven a growing series of investigations from various parts of the world including the United States [16], United Kingdom [17-20] India [21], and Australia [11]. This research focuses on understanding the phenomenon of mental toughness from the perspective of athletes and coaches and has identified a myriad of characteristics that are ascribed to mental toughness. Interestingly, many characteristics have been generally identified among self-confidence, concentration and focus, motivation, growing competition, resilience, handling pressure, positive attitude, quality preparation, goal setting, determination and perseverance, and commitment.

\section{B. Match Simulation}

Simulation is a training technique in which the trainer incorporates common disturbances into training sessions or drawings to help athletes get accustomed to stimuli that create unwanted oriented responses [22]. In addition, once mental toughness has been developed, athletes feel that several mechanisms are needed to underlie the maintenance of this construction. For example, the use of various mental skills and strategies, simulation training and the establishment of a reliable and reliable social support network that supports the maintenance of mental resilience [23].

Competition techniques where the user of the technique must be permanent, specifically for the match, but it is difficult to adapt it to the environment, preparation of the technical form of each athlete and the level of resistance of each opponent. So the technique will not improve or only reach a normal level, or only in ideal conditions. So the technique can improve if everything is arranged according to the athlete's abilities and situations similar to a match. Ozolin considers that changing simulation of match days with rest days is an important factor in the athlete's adaptation to the match schedule [24]. Some programs can be developed such as imitations that can improve athletes' achievements throughout the upcoming match [25].

1) Simulation practice strategy: Practicing through simulations makes athletes accustomed to the atmosphere of the match they face. During the training process the trainer must provide a simulation exercise by presenting bad possibilities in the exercise. In a badminton training session for example, when an athlete is competing with an opponent who has a balanced ability, his support friends who sit around the side-lines give cheers and support, say loudly, corner the player, or hide the sound of the cassette in his tape recorder. This condition provides athletes with the experience of competing in order to be able to overcome the "nervous" feeling and competition atmosphere that has been felt in routine training [26].

2) Types of simulation exercises:

- Sociodrama: learning methods play a role to solve problems related to social phenomena, problems involving relationships between humans such as the problem of juvenile delinquency, drugs and so on. Sociodrama is used to give understanding and appreciation of social problems and develop students' ability to solve them.

- Psychodrama: a method of learning by playing roles that starts from psychological problems. Psychodrama is usually used for therapy, namely so that students get a better understanding of themselves, find self-concepts, express reactions to the stress they experience.

- Role playing: learning methods as part of a simulation aimed at correcting actual events, or events that may arise in the future. Topics that can be raised for role playing, for example, play the role of a party campaigner or a picture of the situation that emerged in the information technology age.

- Peer teaching: teaching exercises conducted by students to fellow teacher candidates. Besides peer teaching is a learning activity carried out by a student to other students and one of the students better understands the subject matter.

- Game simulation: role playing, students compete to achieve certain goals through games by meeting predetermined rules. Based on the types of simulation 
exercises described, the types of simulations that the authors use in this study are game simulations in the form of actual match simulation exercises.

3) Aspects of simulation exercises: In a simulation exercise, the trainer can try to include tensions in the training session so that the training session can be realistic. Tensions created according to senhouse can be in the form of: 1 . Noise, 2. Audience, 3. Bad referees' decisions, 4. Arena match, 5. Fatigue and 6. Practice when new athletes eat [27].

The advantages of using simulation exercises explained by Dharma include [26]:

- Can be used as a provision for students to face the actual situation later, both in family life, society, and in the world of work.

- Can develop student creativity, because through simulation students are given the opportunity to play a role in accordance with the topic being simulated

- Can foster student courage and confidence

- Enriching the knowledge, attitudes and skills needed to deal with various problematic social situations

- Can increase student passion in the learning process.

\section{Personality}

Personality is a translation of the English personality. The word personality itself comes from the Latin personal meaning mask used by actors in a game or performance.

In everyday life, the word personality is used to describe: (1) a person's identity, one's identity, such as: "I am an open person" or "I am a quiet person," (2) a person's general impression of yourself or someone else, such as "He is aggressive" or "He is honest", and (3) functions of a healthy or problematic personality, such as: "He is good" or "He is vindictive" [28].

Based on the attitude of his soul, humans can be classified into two types, namely as follows:

- Humans are types of extraversions, and

- Humans of the type of introversion.

Extroverted people are mainly influenced by the objective world, the world outside of themselves. His orientation is primarily outwardly oriented. His thoughts, feelings, and actions are mainly determined by his environment, both the social environment and the non-social environment. Extraversion type people are positive towards their society, open hearted, sociable, and effective relationships with others. The danger of this type of extraversion is if the attachment to the outside world is too strong, so that he is immersed in the objective world, loses himself or is alien to his own subjective world.

The type of introversion is mainly influenced by the subjective world, that is, the world within itself. His orientation is primarily focused on himself, his thoughts, feelings, and actions are mainly determined by subjective factors. Adjustment to the outside world is not good, his soul is closed, difficult, sociable, difficult to deal with other people. Adjustment to his own mind is good. The danger of this introverted personality type is that if the distance from the objective world is too far, the person is separated from the objective world [28].

\section{Basketball}

Today, basketball is the fastest growing sport in the world for various reasons. First, basketball is a very popular sport, especially on television. Broadcast NBA events throughout the world and men's and women's college competitions nationally have influenced many young athletes to participate in sports. The growth of international basketball has created more excitement and participation. At present, more than 200 countries have a basketball federation. Basketball is a sport for everyone. Although this is a very young sport, it is played by women and men of all ages, physically handicapped people, including people in wheelchairs. Participation between older players and female players is increasing.

Basketball is a team game where you can help your team by improving your individual skills. Basketball requires the integration of individual talent into unselfish team play. This requires good execution of basic skills, which, once learned, can be linked to the whole game. Basketball training installs confidence, transferring skills to game situations, and contributes to long-term enjoyment [29].

\section{CONCLUSION}

Coaches and athletes deliberately challenge different challenges according to form, content, time, place of origin, and level of difficulty to build athletes in the athlete's career. Therefore, match simulation is important in a training program that opposes the long term. Practicing through simulations makes athletes compatible with the matches they face. The trainer in the training process must provide a simulation exercise by giving a poor assessment in the exercise.

The latest research above about mental toughness shows that in building mental toughness, sports psychologists state that coaches must have goals, both intentional, wise and systematic goals. The coach is recommended to build the mental toughness of athletes through match simulations. Where athletes are given a variety of situations with various pressures to develop athlete mental toughness. Good seen from athletes who have extrovert and introvert personality in basketball.

\section{REFERENCES}

[1] P., Meletakos, Chatzicharistos, D., Apostolidis, N., Manasis, V., and Bayios, I, "Foreign players and competitive balance in Greek basketball and handball championships," Sport Management Review, vol. 19(4), pp.391-401, 2016

[2] R., Weinberg, Freysinger, V., and Mellano, K. "How can coaches build mental toughness? Views from sport psychologists," Journal of Sport Psychology in Action, vol. 9(1), pp.1-10, 2018.

[3] T. V., Ryba, Stambulova, N. B., and Wrisberg, C. A. "Forward to the past: Pun's model of volitional preparation in sport," International Journal of Sport and Exercise Psychology, vol. 7(3), pp.275-291, 2009.

[4] L., Crust, and Clough, P. J, "Developing mental toughness: From research to practice," Journal of Sport Psychology in Action, vol. 2(1), pp.21-32, 2011. 
performance," Research quarterly for exercise and sport, vol. 73(2), pp. 175-186, 2002.

[5] V. H. A., Okazaki, Rodacki, A. L. F., and Satern, M. N, "A review on the basketball jump shot", Sports Biomechanics, vol. 14(2), pp. 190-205, 2015.

[6] K., Narazaki, Berg, K., Stergiou, N., and Chen, B, "Physiological demands of competitive basketball," Scandinavian Journal of Medicine and Science in Sports, vol. 19(3), pp. 425-432, 2009.

[7] M., Farrell, "Leadership Reflections: Extrovert and Introvert Leaders," Journal of Library Administration, vol. 57(4), pp. 436-443, 2017.

[8] M.D. Lieberman, and R. Rosenthal, "Why introverts can't always tell who likes them: Multitasking and nonverbal decoding," Journal of personality and social psychology, vol. 80(2), pp.294, 2001.

[9] C.G. Wiley, S.M. Shaw, and M.E. Havitz, "Men's and women's involvement in sports: An examination of the gendered aspects of leisure involvement," Leisure Sciences, vol. 22(1), pp. 19-31, 2000.

[10] D., Neumark-Sztainer, C. Goeden, M. Story, and M. Wall, "Associations between body satisfaction and physical activity in adolescents: Implications for programs aimed at preventing a broad spectrum of weight-related disorders,"Eating Disorders, vol. 12(2), pp. 125-137, 2004

[11] D. Gould, S. Jackson, and L. Finch, "Sources of stress in national champion figure skaters," Journal of sport and exercise psychology, vol. 15(2), pp. 134-159, 1993.

[12] T. Orlick, and J. Partington, "Mental links to excellence," The sport psychologist, vol. 2(2), pp. 105-130, 1988

[13] K. Kreiner-Phillips, and T. Orlick, "Winning after winning: The psychology of ongoing excellence," The Sport Psychologist, vol. 7(1), pp. 31-48, 1993.

[14] D.A. Sinclair, and T. Orlick, "Positive transitions from highperformance sport," The sport psychologist, vol. 7(2), pp. 138-150, 1993

[15] J.R. Potgieter, and S. Fourie, "The nature of mental toughness in sport," South African Journal for Research in Sport, Physical Education and Recreation, vol. 23(2), pp. 63-72, 2001.

[16] D. Gould, C. Greenleaf, Y. Chung, and D. Guinan, "A survey of US Atlanta and Nagano Olympians: Variables perceived to influence
[17] M. Bull, "Thinking medieval: An introduction to the study of the middle ages," Springer, 2005.

[18] T. Fawcett, "Perceptions of mental toughness from adventurer/explorer/"medal winning'elite athlete and elite coach perspectives: A grounded theory analysis," In Psychology promoting health \& performance for life: Proceedings of the ISSP11th world congress of sport. Sydney: International Society of Sport Psychology, 2005 .

[19] G. Jones, S. Hanton, and D. Connaughton, "What is this thing called mental toughness? An investigation of elite performers," Journal of Applied Sport Psychology, vol. 14, pp. 205-218, 2002.

[20] R. Thelwell, N. Weston, and I. Greenlees, "Defining and understanding mental toughness within soccer," Journal of Applied Sport Psychology, vol. 17(4), pp. 326-332, 2005.

[21] S. Gordon, and S. Sridhar, "Identification and development of mental toughness," In ISSP 11th World Congress of Sport Psychology, Sydney, Australia, 2005

[22] D. Burton, and T.D. Raedeke, "Sport psychology for coaches", US: Human Kinetics, vol 3, 2008.

[23] F. Daniel, Gucciardi and S. Gordon, "Mental Toughness in Sport Developments in theory and research," Routledge, 2011.

[24] N.G. Ozolin, "Athlete's training system for competition. The role and sequence of using different training-load intensity," Bondarchuk, A, ed. Escondido: Sports Training, Inc, pp.202-204, 1971.

[25] O., Tudor, Bompa. Theory And Methodology Of Training, 1988.

[26] S. Dharma, "Strategi pembelajaran dan pemilihannya," Jakarta: Direktorat Tenaga Kependidikan Departemen Kependidikan Nasional, 2008.

[27] Alwisol, "Psikologi Kepribadian," Malang: UMM Press, 2009.

[28] S. Yusuf and J. Nurihsan. "Teori Kepribadian”, Bandung : PT Remaja Rosdakarya, 2012.

[29] H. Wissel, “Basketball: Steps to success.,"Human Kinetics, 2011. 